\title{
The public visibility of Islam and European politics of resentment: The minarets-mosques debate
}

\section{Nilüfer Göle}

Ecole des Hautes Etudes en Sciences Sociales, CESPRA, Paris

\begin{abstract}
The public visibility of Islam reveals new political stakes in European democracies around issues of immigration and citizenship. By focusing on the societal debates and the controversies around the construction of mosques and minarets, this article explores the ways in which Islamic difference is manifested, perceived and framed in public life. The 'visibility' of Islam in public is conceptualized as a form of agency, a manifestation of religious difference that cannot be thought independent of the materiality of culture, namely aesthetic forms, dress codes, or architectural genres. It is argued that the debates for or against the banning of the construction of mosques and/or minarets reveal the tumultuous transition of Muslims from the status of the invisible migrant-worker to that of visible Muslim citizenship. The public visibility is approached therefore as a radically disruptive, transgressive, provocative form of transformative agency that is intrinsically related to the political process of becoming citizens.
\end{abstract}

\section{Keywords}

citizenship, European publics, interpenetration, Islam, public sphere, religious difference, visibility

\section{Lost 'innocence' of mosques}

Islam acquires new cultural forms, subjectivities and public visibilities as it passes from eastern lands to Europe. In this process of transition Muslims face unprecedented issues,

\author{
Corresponding author: \\ Professor Nilüfer Göle, EHESS, CESPRA \\ Email: nilufer.gole@ehess.fr
}

A version of this article was presented at the Reset-Dialogues istanbul Seminars 2010 that took place at Istanbul Bilgi University from May 19-24, 2010 
both at the level of their everyday life experiences and in terms of Islamic theology and law. Muslims find themselves outside the Muslim lands (dar-ul Islam), follow Islamic prescriptions in a secular environment, discuss Islamic law without an Islamic state, and discover themselves as a minority group. The displacement of Islam with its reterritorialization in Europe alters the religious practices and subjectivities of Muslims, but also involves 'autochthones' and defies citizens to redefine the place of religious difference in secular Europe. Far from taking place in a linear and quiet process of immigration, adaptation and accommodation, the eruption of Islamic presence in public life disrupts the shared collective imaginaries and self-perception of Europeans. During the last three decades, one witnesses the ways in which the visibility of Islamic signs and symbols in the European public life becomes a major source of cultural dissonance and political dispute. Debates on the construction of minarets and mosques in the European landscape are such examples. On the one hand they illustrate the process of reterritorialization of Muslims and concomitantly the visibilization of Islamic religious signs and symbols in Europe. On the other hand the debates on the construction of mosques and minarets reveal the ways European publics deal with Islamic religious and cultural difference. In sum, the debates over construction of mosques cease to be an issue only for citizens of Muslim confession, but become a concern for all, a public issue that both divides and reassembles citizens of different political convictions, religious confessions and national origins.

When and how does a familiar object, a religious sign, become visible to public eye and a matter of public debate? For Muslims a mosque with its minarets is not only a place of worship but also a cultural artifact that is part of a familiar landscape. Furthermore a mosque is also a public space open to all pious citizens, a space of religiosity and sociability, it is not a monument that is isolated and stands on its own but is surrounded by a complex, comprising seminar rooms, hammam, bookstores, shops. It was during the Iranian Islamic revolution of 1979 that mosques became a focus of attention as they represented places from where the revolutionary fervor and preaching spread out. ${ }^{1}$ Therefore not only in European contexts, but also in Muslim-majority countries, mosques, became a visible site that crystallizes the convergence of different issues related with urbanism, pious publics and political Islam.

We can speak of the 'loss of innocence' of mosques in modern times, as they become sites that are not merely confined to the needs of the pious and local inhabitants but draw political attention and public debate. In other terms, the mosque as a religious public sphere is no longer restrained within the boundaries of a community of believers, but claims its visibility and participation in the public sphere at large, both at national and global scales, thereby defying the divide between religious and secular spheres, between personal piousness and secular publicness. Before discussing the European context in which mosques become a source of politics of suspicion and resentment, I will evoke some elements of the ways mosques focus public attention, a battleground among citizens in a Muslim-majority country such as Turkey.

How can the historic and cultural symbols of Islam in a Muslim-majority country like Turkey cease to be parts of the field of a familiar, peaceful and immutable heritage, and begin to develop a new visibility in public and awaken religious and political divisions? One should therefore approach the public sphere not as a fixed, established entity, but as a malleable process of 'visibilization', awareness and confrontation of differences, and ask when 
and how a symbol, or an object, which is to us so familiar as to have become imperceptible, becomes one day 'visible' - nay, ostentatious and disturbing to the eyes of a public.

Istanbul with its mosques and the silhouettes of its long-lined minarets seems to have been there for ever, offering us a peaceful scenery and a sense of immutable past in the midst of its undergoing an unprecedented change. Without its slender minarets, elevating spiritually beyond the hectic and chaotic energy of the profane, the city would certainly lose a part of its aesthetic appeal but also of its soul in the eyes of its inhabitants, Muslim and non-Muslim. But the accelerated construction of mosques since the 1950s undergoes criticism. The secular publics resent their proliferation as a sign of the popularity of Islam and many regret that the new mosques built in contemporary Turkey are far from equaling those of the great architect Mimar Sinan (d. $1588 \mathrm{CE}$ ), who worked during the glorious days of the Ottoman Empire. The massive construction of mosques is subject to criticism for their lack of aesthetics and harmony with their disproportionate dimensions between the dome and the minarets. Likewise, the calls to prayer, since the adoption of cassettes and loudspeakers, have become a source of an ongoing public debate over whether they constitute a nuisance to the auditory environment. But debates around mosques are not confined to these subjects on the regulations of sounds and architectural forms of mosques. The projects of reopening Hagia Sophia as a place of prayer for Muslims and of constructing a new mosque at Taksim Square in the heart of Istanbul have given rise for the last decades to an intense and divisive debate between those who see in these attempts signs of Islamization and those who claim the right to exercise their religious freedom. The politicization of mosque debates continued and reached its summit with a poem recited in public by Recep Tayyip Erdoğan, the current prime minister of Turkey, on the occasion of his victory in the 1997 local municipal elections. In the poem the minarets were compared to bayonets, mosques to barracks and Muslims to soldiers. The military metaphors used in the poem for religious symbols contributed to their 'loss of innocence' and deepened the secular resentment. Erdoğan was sentenced and jailed for 'incitement to religious hatred' for having recited these verses which are attributed to one of the nationalist poets who wrote them in the context of the war for national independence at the beginning of the $20^{\text {th }}$ century. But the citation of the poem in the contemporary context was trapped within the dynamics of polarization between secular and religious politics, acquired a different meaning, and spread the politics of suspicion and resentment over mosques and Islam beyond the Turkish borders. As we will see in the section below, the poem was used by anti-minarets campaigns in Europe.

\section{Mosques as interface}

Let me now turn to European contexts in which debates on the legislation for construction of mosques and minarets are becoming central issues in the European public and political life across the national borders. The Swiss referendum (29 November 2009) which enacted, by a popular majority vote, the ban on constructing minarets reveals to us this new, disturbing visibility of Islam in the eyes of the European public. ${ }^{2}$ But at the same time, the debate confirms a major shift from the paradigm of social and economic issues related with immigration to that of religion and citizenship issues in public. 
The passage of Islam to the West confronts Muslims with a series of novel questions, which lend European Islam its distinctive traits. A Europeanized Islam exacerbates the paradox of visibility and invisibility. Unlike in Muslim-majority countries, in Europe the mosques are discreet and indistinguishable, and the minarets are mute. The majority of Muslims do not seek to make their religious obedience visible to the public eye. There are strategies of invisibility as much as that of visibility among Muslims themselves. Some European political leaders, however, with a view to both security and openness, have sought to increase the visibility of places of worship, inviting Muslims to construct mosques and attend them in daylight instead of hiding in the basements and garages.

However, the significance of allowing the mosque its visibility is not self-evident; the positioning of the mosque in the urban space, its architectural forms and the population invited to inhabit there, all are subject to debate and decision in a European context. Construction of a mosque near a cathedral in the center of the city, such as in Cologne, triggers a series of questions that are not raised if the mosque is planned to be constructed in the outskirts, the abandoned-manufacturing areas of a city. Even the simplest design decisions can reflect questions that are crucial to citizens of the Muslim confession as well as to those who are not. Should a mosque always have a dome and a minaret? Although a mosque is not considered to be a sacred place like a Christian church and for a Muslim 'the whole world is a mosque', and a Muslim can turn the global earth into a prayer mat, ${ }^{3}$ mosques represent the imprint of Islamic cultural heritage and power. In spite of the fact that one can find and construct mosques without minarets and domes, the minaret together with the dome has become a 'structural metonym' of Muslim identity. ${ }^{4}$ Can we have a mosque that would not be identifiable as such? Should we separate, as the Swiss seem to wish, the minarets from the mosques? Can we replace the word 'mosque', a word that some seem to fear, with terms such as 'Islamic community centers' and 'cultural institutes'?

In Europe, minarets and mosques face 'existential' problems; architectural forms, visibility and audibility, degree of publicness of mosques, come under a suspicious public eye, but also become an 'interface' among citizens of different confessions. Constructing a mosque and a minaret in Europe requires a series of negotiations, involving Muslims from different religious communities, urban planners, architects and local authorities. Mosques raise new questions for Muslims living in a non-Muslim immigrant land. How to find a new architectural form that will not simply duplicate the mosques of the 'homeland'?' How can the mosque rally different ethnic communities? Do, for example, Turks frequent the mosques of Pakistanis in Birmingham? Are the Turkish mosques of Berlin also frequented by North Africans and other Muslim minorities? By which criterion should one decide the language of the sermon? How to organize the mosque space in conformity with gender equality and gender separation? The mosques are in the process of being 'updated'; this is a challenge for the $21^{\text {st }}$ century. ${ }^{6}$ How might one re-conceptualize the mosque as a public space, comprising religious seminars, language classes and leisure activities, and try to reach out to non-pious communities as well? All of these questions are crucial in light of the real lives and daily experiences of Muslims in Europe. The mosque is an interface between the urban environment, Muslim citizens and religious pluralism. Accepting its visibility leads to a series of 
negotiations and regulations - aesthetic, religious, financial, architectural and spatial in nature - in the process of making it become an object of a common heritage. ${ }^{7}$

Considered in this light, the Swiss referendum has imposed the non-negotiable; it put a brake on the processes of evolution, exchange and cultural borrowings. The referendum has forbidden the social experimentation and mutual learning and negotiation among actors of different political convictions and religious confessions and thereby betrayed the democratic ideal of an 'open society'.

\section{Visibility and proximity: Islamic transgressions}

There are numerous Islamic centers, mosques built ad hoc and many prayer halls across Europe and their numbers are growing while many churches are empty or converted to different activities. However, temporary and hidden mosques without a distinctive, recognizable feature in suburban industrial zones, in centerss of immigrant workers and working places, do not stir public unrest. ${ }^{8}$ It is the sign of Islamic exceptionalism, its visual religious and cultural difference in the city centers, and the awakening piousness of Muslims that provoke public controversies around mosques across Europe.

The notion of visibility is crucial to understand the ways in which it underpins power relations; it gives evidence of proximity with one another and yet maintains difference. Visibility refers to a choreography of social actors that cannot be fully rendered within the normative framework of 'recognition of difference' that privileges state action (recognition) and takes the category of religion as a given and fixed. However, the category of religion is malleable and adoptable, subject to new ways of learning and transmission (in contexts of displacement), giving birth to new material forms and distinctive features of Islam. Visibility manifests Muslim politics of piousness, namely covering and praying practices that are embodied and spatial, with specific material and aesthetic forms. It translates the sensorial and material power of the Islamic selffashioning into its self-presentation in public. If Islamic distinction is carried, elaborated and fashioned by Muslim pious subjectivities, it becomes also publicly visible and perceivable. Visibility therefore is a notion that relates both strategies of personal piousness and public perceptions of Islamic difference, lived in proximity, namely in the same public space that constitutes the grammar of power relations. Islamic signs and symbols become visible and have a disruptive effect in European public imaginaries to the extent that they manifest Muslim presence in spaces that were not reserved to them and in anachronism with the established values. Islamic visibility signifies a process of spatial transgression of Muslims and their religious difference, disobedience to secular and cultural norms, and dissonance against tacit consensus that underpins European publicness. In sum, Islam crosses the geographical borders by means of immigration, but it also transgresses the invisible cultural boundaries of the European public sphere.

\section{Populist nationalism and Islamophobia}

It is around the theme of Islamic visibility, in large part, that collective passions and public debates are mobilized today. The headscarf at school, the burka in the street, the 
mosque in the city and the minarets in the landscape indicate the disturbing presence of Muslim actors in daily life.

In the first place, the public visibility of religious and cultural signs of Islam expresses the presence of Muslim actors in European countries. The minarets - as, in other respects, the veils, the other mute symbol - reveal the Muslim actor - as pious, as feminine - in public life. This visibility attests to the presence of Muslims in European societies, their desire to stay there, their claim to the freedom of conscience, and their right to worship and dress according to their personal interpretation of their religion. Islam, in a paradoxical way, has become a political and cultural resource for the singularization of immigrants, for their quest for recognition, and so it indicates in turn their particular citizenship in the public space of Europe. This new visibility marks the end of a stage in the migratory phenomenon and in the integration, lived experience and modes of appropriation of public space in Europe. Muslims manifest their presence by means of their religion; hence they break away from public indifference in relation to them, and appropriate spaces in which they are not welcomed. Veiling in the public schools and Muslim candidates in the parliament, mosques near the churches and the cathedrals, praying in the streets, all are examples that make 'indifference' impossible for Europeans who find themselves in a passionate debate over the presence of Islamic signs in public life. However, these confrontational controversies around Islam reveal the tumultuous transition and recognition from the status of an invisible migrant to that of a visible Muslim citizenship.

Therefore one can argue that the debates on the minarets and their ban bear witness to the difficulty in Swiss society of recognizing the presence of newly settled Muslims, and of making a place for them in public life. The sentiment that Islam is invading their territory, the fear of losing one's 'home', has been widely expressed during these debates. In speeches, Muslims have been asked to install their minarets 'back home'; in posters they have been compared to dangerous 'black sheep'; they are considered to be 'strangers' and are thus symbolically expelled. The leitmotiv of the debate, to protect oneself and one's home from this allegedly conquering religion, hides the reluctance to renounce the monopoly of Swiss-born citizens on their public space. All the semantics of the debate lead us to think that the battle over territory and its equation with a 'nation' (and in some cases with a 'race') not only expresses the difficulties of framing Muslim claims within rights of citizenship, but also reveals a dynamics of populist politics that retreats away from inclusionary pluralism. The undemocratic character of this vote resides in its expression of a desire to contain and fix public space in strict equivalence with an essentialist conception of the nation, without opening it to the plurality of citizens. In another respect, Muslims, with their multiple attachments - to languages, ethnic groups, religion and the ummah - disrupt the national definition of citizenship and arouse suspicion of their loyalty. The definition of a public space which is identified with a pre-established national community can only create tensions and exclusions in a world traversed by migratory and transnational dynamics, be they religious, economic, or cultural.

The referendum, far from staying confined to the Swiss context, has resonated in other national contexts and has given a transnational, European dynamic to the debate. Some deplore the Swiss error as one not to be repeated; others have applauded the 
courage to have said out loud what everybody thinks in a whisper. Polls conducted in France have revealed a favorable opinion of the limitation on the construction of mosques. The British National Party (BNP) has appropriated the 'anti-minarets' poster used by its Swiss counterpart (UDC). This poster shows the national flag (Swiss or British, respectively) pierced by minarets represented as guns. There appears as well a woman in full veil. In the English versions, the above-mentioned verses recited by Tayyip Erdoğan are included. In public debates throughout Europe, these same verses have incessantly been taken out of context. One sees how the debate on the minarets in particular, and the visibility of Islam in general, generates transnational dynamics and assemblages of disparate elements. One observes that even insular Britain and Switzerland, isolated from Europe, enter the European public field. The fear of Islam instrumentalized by different populist parties and 'anti-Islamization politics' finds resonance within the silent majority. Marginal political figures - such as Oscar Freysinger in Switzerland, Geert Wilders in the Netherlands and Philippe de Villiers in France - have contributed to the transformation of national political agendas across Europe and have won popularity in their fight against the Islamic presence in Europe. In France, Marine Le Pen joined the club of these popular figures, by shifting the political discourse of her father's extreme-right party (Front National) from anti-immigrant discourse to a new agenda fueled by Islamophobia. Her comments recently sparked a debate when she said that 'Muslims praying on the streets in some neighborhoods were like Nazi occupiers', remarks that resonate with the Swiss anti-minaret vote. ${ }^{9}$

In a sense the question whether Muslim immigrants are integrated or not in European societies becomes obsolete and irrelevant to the extent that Islam becomes vigorous in the shaping of European public life and politics. ${ }^{10}$ In this post-immigration phase, not only do Islamic signs and symbols become more visible in public but also 'Islam' (whether it is appropriated or rejected) makes people publicly more audible, visible and transnational. These new figures of politics of 'anti-Islamization' owe their popularity to their engagement with Islam. They have changed the agenda of the extreme right from xenophobia and anti-immigration politics to that of 'Islamophobia' ${ }^{11}$ while adopting a discourse of gender equality, gay rights and secularism. The populist right in Europe gains new faces - young, female, gay - and distinguishes itself from the previous generation of extreme-right politicians who were representatives of patriarchal authority, sexist discrimination and anti-Semite politics. In their mobilization against Islam, they become defenders of the hyphenated 'Judeo-Christian' civilization, national values, gay and women's rights. They make use (and abuse) of the post-'68 leftist progressive agenda in the fabrication of politics of fear and resentment. The conflation between the progressive agenda of the post-' 68 and extreme-right racism unsettles the established divide between the right and the left, between the extreme politics and the mainstream opinions. Both leftist intellectuals and center-right politics are challenged and even disempowered by the rise of these new populist discourses that fuse fear and prejudice against Islam to reach publics.

The current political populism gains ground in Europe, a home for a democratic public sphere with a tradition of an 'enlightened public'. The use of reason and the distinction between opinion and truth have been historically established and considered as a democratic feature of European public spheres. Populist politics makes use of fear and 
prejudices to appeal to the domain of the personal, the visceral and the sensational. The public sphere is at risk of losing its role as the ideal expression of democracy and becoming a place of common sense, of the sanctification of public opinion, and of the contagion of the sensational and scandalous. It is by such regression of public debate towards the irrational and the emotional that the Swiss vote can be considered as a betrayal of the democratic ideal.

\section{Publics in confrontation, publics in the making?}

The politics of confrontation with Islam leads to the renewal and rejuvenation of a populist right movement that fuels the resentment of some as it deepens the stigmata of others. However, on the other hand, these debates instigate a deeper change in the process of the making of European publics. The confrontation over issues of Islam brings different publics together, in proximity with each other in unprecedented ways. It creates new coalitions and constellations in terms both of political lines and of cultural boundaries as well as across European borders. People from very different horizons find themselves in proximity, in the same constellation. In following the way Bruno Latour poses the question 'What makes things get public', one can put the emphasis on the making of the public, on the ways people and things come to be related, on the 'assemblages'. ${ }^{12}$

There is an intrinsic relation between getting public, visibility and agency as it is elaborated by Hannah Arendt. ${ }^{13}$ To appear always means to seem to others. It is perceived by a plurality of spectators, therefore a public is by definition pluralistic. And therefore citizenship is not prior to public appearance but one becomes a citizen as one makes oneself visible to others. Muslim actors manifest their difference by means of religious difference, but in doing so they manifest also their citizenship. The questions of citizenship are always political because politics deals with difference and conflict; as one makes oneself visibly public, one also marks the transgression of boundaries and the disruption of the established frame.

Publics as I argue are not pre-established and consensual entities, but constituted by manifestation of differences, their confrontation with each other and their mutual transformations. Confrontation leads as well to a process of 'interpenetration' ${ }^{14}$ that comprises physical proximity, force and incursion in one another's cultural domain.

The force of symbols, the importance of visual culture and performative practices but also the politics of humor and subversion can be observed in the newly emerging European public sphere. Two different examples that have followed the minaret ban in Switzerland testify to the role of aesthetics and humor as well as individual citizens in the making of publics cross-culturally. A non-Muslim Swiss citizen, Guillaume Morand, protested against the minaret ban by constructing a minaret on the top of his roof in Lausanne. ${ }^{15}$ A group of Muslims living in Europe organized a contest for the most beautiful minaret in Europe. ${ }^{16}$

Visibility as a form of agency in public brings also the domain of culture and the personal under public attention; visibility as a form of agency comprises materiality of culture, aesthetic forms, dress codes, or architectural genres. It can be performative as in the case of religious rituals and public praying but also new secular rituals with pig parades for the aim of desecrating the plots of lands newly bought by Muslims for 
mosque constructions, ${ }^{17}$ or public gatherings around drinking wine and eating ham. ${ }^{18}$ Visibility is a form of agency sometimes mute and not always discursive, but certainly a form of agency that is radically disruptive, provocative and mutually transformative.

\section{Notes}

1. For an analysis of religious sociability, the changing role of Friday prayer and the mosques in Iran since the revolution, see Fariba Adelkhah, 'Iran: vers un espace public confessionnel?', Les Etudes du CERI 27 (June 1997): 1-33.

2. Patrick Haenni and Stéphane Lathion (eds) Les Minarets de la discorde. Éclairages sur un débat suisse et européen (Fribourg: Religioscope, 2009).

3. For an intellectual and performative exercise inspired by this Islamic principle concerning the mosque, see Azra Akšamija, 'Nomadic Mosque: Wearable Mosque Spaces for Contemporary Islamic Practice in the West', Thresholds 32 (2005): 17-21. Here she argues that the minute Muslims turn to Mecca to perform their prayer they transform any space into a mosque.

4. Nebahat Avcioglu, 'Identity-as-Form: The Mosque in the West', Cultural Analysis 6 (2007): 91-112 (92).

5. Ergün Erkoçu and Cihan Buğdacı (eds) The Mosque: Political, Architectural and Social Transformations (Rotterdam: Nai Publishers, 2009). See especially the article by Roemer van Toorn, 'Countering the Clash of Culture: Mosque Architecture as an Emancipating Factor', in ibid., pp. 107-13.

6. Carla Power, 'Updating the Mosque for the $21^{\text {st }}$ Century', Time magazine, 2 April 2009; available at: http:/www.time.com/time/magazine/article/0,9171,1889047,00.html

7. All these issues were raised during my fieldwork research conducted in Switzerland just after the referendum in December 2009. The Experimental Group Discussion in Geneva was realized within the framework of the 'EuroPublicIslam' project that I currently direct. My research project has received funding from the European Research Council under the European Community's Seven Framework Programme (FP7/2007-2013), Grant Agreement no. 230244. See the web page: http://europublicislam.ehess.fr/

8. For a very comprehensive research on mosques, see Stefano Allievi, Conflicts over Mosques in Europe: Policy Issues and Trends (London: NEF, 2009), especially pp. 38-50. See also Marcel Maussen, Constructing Mosques: The Governance of Islam in France and the Netherlands (Amsterdam: University of Amsterdam Press, 2009).

9. 'Marine Le Pen: Muslims in France "like Nazi occupation"', 12 December2010, available at: http://www.telegraph.co.uk/news/worldnews/europe/france/8197895/Marine-Le-Pen-Muslimsin-France-like-Nazi-occupation.html

10. As the title of my research project attests: see Nilüfer Göle, 'Islam in the making of a European Public Sphere', in 'EuroPublicIslam', at: http://europublicislam.ehess.fr/

11. Vincent Geisser, La Nouvelle Islamophobie (Paris: La Découverte, 2003).

12. Bruno Latour and Peter Weibel (eds) Making Things Public: Atmospheres of Democracy (Cambridge, MA: MIT Press, 2005).

13. Hannah Arendt, The Life of the Mind, vols 1 and 2 (New York: Mariner Books, 1981).

14. Nilüfer Göle, Interpénétrations: L'Islam et l'Europe (Paris: Galaade Editions, 2005); the English-language translation has recently been published: Nilüfer Göle, Islam in Europe: 
The Lure of Fundamentalism and the Allure of Cosmopolitanism, trans. S. Rendall (Princeton, NJ: Markus Wiener, 2010).

15. 'Suisse: "J'ai construit ce minaret pour protester", Rue 89.Com, 9 December 2009, available at: http://www.rue89.com/2009/12/09/suisse-jai-construit-ce-minaret-pour-protester-129353

16. 'Mosque in Bradford with Four Minarets wins Prize', Islamist Watch, 20 April 2010, available at: http://www.islamist-watch.org/3740/europes-most-beautiful-minaret-at-uk-mosque

17. Allievi, Conflicts over Mosques in Europe, p. 39.

18. 'Saucisson-pinard: quand l'apéro géant devient discriminatoire', Rue 89.Com, 14 June 2010, available at: http://www.rue89.com/mouloud-akkouche/2010/06/14/saucisson-pinard-quandlapero-geant-devient-discriminatoire- 154815

In Paris, a group of people organized this get-together in Goutte D'Or area, a neighborhood considered 'totally lost to Muslims', a place at the heart of Paris 'where nothing is left as French or Parisian'. 